\title{
O trabalho feminino na Grécia Antiga: lenda e realidade ${ }^{1}$
}

\author{
Maria de Fátima Silva \\ Universidade de Coimbra \\ Portugal
}

\begin{abstract}
Resumo. Este artigo avalia, numa perspectiva diacrónica, o trabalho feminino na Grécia antiga e a sua evolução a partir da época arcaica até à clássica, com recurso aos testemunhos da épica e do teatro. São tidos em conta o modelo de organização social, mais aristocrático ou mais democrático, ou factores determinantes no quotidiano, como a guerra, a instabilidade populacional, as condições económicas.

Palavras-chave. Poemas homéricos; teatro; tragédia; comédia; trabalho doméstico e cívico; lazer.
\end{abstract}

Muitas são as cambiantes que o trabalho humano desde sempre revestiu, como um elemento vital na organização e na sobrevivência das sociedades. E porque um dos seus encadeamentos naturais o liga ao sexo, na medida em que sempre tendeu a ser distinta a expectativa colectiva perante o trabalho do homem e da mulher, é ao labor feminino que nos vamos dedicar. É por demais reconhecida a condição de reclusão doméstica, bem como a discrição de comportamento que a Grécia impôs à mulher, ainda que, dentro desse quadro, a situação não se tenha mantido imóvel; sinais evidentes de oscilação entre uma maior ou menor intervenção ou visibilidade são inegáveis, de acordo com um certo modelo de organização social, mais aristocrático ou mais democrático, ou em consequência de factores determinantes na alteração do quotidiano, em que a guerra funciona como condição de relevo; em consequência de um conflito, a instabilidade populacional, a par da revolução nas condições económicas, incide inevitavelmente na gestão do trabalho e na atribuição de tarefas aos diversos agentes sociais. Quando a ruptura no contexto cívico se faz sentir, afectando o universo comum da pólis e, através dele, o equilíbrio do

Email: fanp@ci.uc.pt

${ }^{1}$ Artigo baseado na conferência apresentada durante o XVI Congresso Nacional de Estudos Clássicos, Ócio \& Trabalho no Mundo Antigo (Araraquara, Brasil, 3-7 de setembro de 2007). 
ôkkos, as barreiras que separam estes dois mundos, expressas nas paredes das habitações, desabam, para exigir uma mescla inevitável entre interior e exterior. A necessidade de sobrevivência e de superação da crise como que estimula, na criatura humana, o sentido gregário e mina hierarquias e contrastes, num apelo à mudança e à coesão. Com esses movimentos sociais, o trabalho doméstico e cívico sofre profundas alterações, que podem ir, na liberdade dos símbolos, até à utopia; a alteração compulsiva da ordem tradicional de vida pode chegar à simples inversão, num mundo fantástico onde a mulher se substitui ao homem, ou onde a cidade, depois de ruirem as paredes das casas, se torna numa morada única.

Dentro do trabalho feminino, em si mesmo, é também patente a intervenção do factor hierarquia ou classe. Muito vincada numa sociedade aristocrática, que separa, com clareza, senhoras e escravas, esta distância tendeu a reduzir-se com a descoberta de um outro modelo de vida colectiva, a democracia. Este é um processo evidente na experiência grega; da tradição cortesã, onde a senhora se distinguia por alguma inércia, ou onde o trabalho que produzia funcionava mais como um espectáculo de requinte do que como uma actividade útil, a mulher foi caminhando, em simultâneo com a redução de distâncias e privilégios, para a exigência de uma maior produção, orientada para as necessidades efectivas do quotidiano. Colaborar na sobrevivência da família passou a ser uma exigência estimulante, que trouxe ao trabalho feminino, em todas as suas variantes, o condicionalismo da obrigação. Talvez aquelas princesas, que a tragédia retrata como cativas de guerra submissas a uma nova autoridade, ou aquelas filhas de família apeadas, por um casamento desigual, das prerrogativas da classe a que pertenciam e forçadas a uma vida activa e penosa, sejam o símbolo evidente de que todas estas mudanças sociais não foram isentas de frustração ou de sofrimento. Por isso, o trabalho foi perdendo a sua face lúdica, de requintado passatempo, para se tornar imposição e necessidade. A literatura sempre encontrou, num jogo de símbolos, forma de dar vida a esta realidade. O requinte dos próprios materiais, o ouro e a prata vinculados aos instrumentos de trabalho, a púrpura e a macieza dos tecidos à raridade dos produtos confeccionados, consagrou o retrato de um requinte que transformava o trabalho em passatempo elegante e em promoção social, distante da realidade comezinha de um quotidiano mais aberto e normalizado, dentro de uma comunidade democrática.

Mau grado as diferenças, o trabalho comportou sempre uma faceta de talento pessoal e de convívio humano, mesmo quando a hierarquia se sentia com maior pressão. O quadro épico da senhora rodeada de servas que com ela colaboram em tarefas domésticas, ao mesmo tempo que a 
entretêm ou com ela convivem em confidências ou partilhas de vida, não deixa, sobre o lado colectivo e social do trabalho, grandes dúvidas. Entre as próprias servas, são também sensíveis as hierarquias, fruto da autoridade ou ascendente que a idade ou o rigor no trabalho conferem. $\mathrm{Na}$ execução de tarefas estão envolvidos traços pessoais ou sentimentos, de capacidade, inteligência, alegria ou tristeza; mas ela será sempre garante de um produto, qualquer que seja a motivação que o suscitou, com um peso, doméstico e social, irrecusável. Como testemunhas deste processo, recorreremos aos textos homéricos e ao drama do séc. V, que, sem quebrar um nexo de tradição e de herança, espelham, de forma nítida, o contexto social distinto que os rodeou.

Se pensarmos no trabalho feminino tal como o retrata Homero $^{2}$, é desde logo patente a hierarquia que o regula; as grandes damas que habitam as cortes em que o mundo grego da época se organiza - e, à sua semelhança, também as casas régias em paisagem bárbara - vivem rodeadas de servas, a quem cabe a execução do que podemos considerar o trabalho efectivo, que responde às necessidades do quotidiano; para si reservam uma coordenação algo distante dentro das suas casas e a execução de tarefas restritas, que se caracterizam por um certo tom de espectáculo de luxo e de requinte. Curiosamente, no espaço épico, os quadros de trabalho mais expressivos relacionam-se com duas figuras femininas, à primeira vista contrastantes pelo destino que cercou as suas vidas, Helena e Penélope. E se, em muitos outros aspectos, a relação entre as duas é oposta, no que às tarefas que executam diz respeito vigora a coincidência, decerto porque ambas obedecem a um paradigma comum. É verdade que a situação em que se encontram é diversa, Penélope assaltada na sua própria casa pelo assédio dos pretendentes a que obstinadamente resiste, na ausência do marido, Helena abrigada em casa alheia, para onde a levou um pretendente bem sucedido, enquanto o marido reivindica, com uma expedição armada, o seu regresso ao lar. O que quer dizer que o dia-a-dia de ambas prossegue com alguma afinidade dentro da inversão de situações: a ambas ameaça a insegurança, a incerteza do futuro, face

${ }^{2}$ Embora seja discutível se há referência a uma realidade concreta por trás da ficção homérica, parece no entanto inegável que os poemas remetem para uma sociedade da Idade do Bronze, afinada por apontamentos do período de tempo em que a tradição dos aedos foi circulando e crescendo. A própria transmissão oral suscita um processo de adaptação às audiências a que a recitação se destina. Sobre este assunto, vide C.G. THомAs, Penelope's worth: looming large in Early Greece, Hermes 116. 3, 257-64, 1988; S. FARron, The portrayal of woman in the Iliad, AClass 22, 15-32, 1979; J.T. KAKRIDIS, The role of the woman in the Iliad, Eranos 54, 21-7, 1956. 
a um conjunto de pretensões pessoais e sentimentais de que são objecto, mas que se não confinam à sua pessoa; através delas, é também o mundo que as cerca que se vê afectado. Helena está privada de uma autoridade doméstica plena $^{3}$, que Penélope preserva no seu palácio de Ítaca; à conta da soberana de Ítaca está 'o seu trabalho, as mulheres, a casa, que lhe cabe vigiar' (Od. 19.514). Mas aquela que é, por excelência, a tarefa feminina - fiar e tecer -, essa aproxima-as, ainda que, também neste caso, o contexto interfira no quadro; um certo isolamento doméstico de Helena em Tróia faz do seu trabalho uma espécie de acto de consciência, solitário e introspectivo; no tecido que lhe sai das mãos, a rainha traça 'as provas sem fim que por ela sofreram, sob os golpes de Ares, os Troianos criadores de cavalos e os Aqueus de armas de bronze' (Il. 3. 125-8)4. De alguma forma a discrição que lhe é exigida, como mulher e na condição falsa em que se encontra, obtém desafogo neste desenho que traça num tecido, que é o espelho de uma alma sofrida e de uma inteligência que se mantém atenta ao mundo de actores masculinos que a cerca. Numa atitude que tem sido comparada à própria criação poética ${ }^{5}$, Helena regista os acontecimentos à medida que vão sendo construídos pelo quotidiano dos heróis. Este é, talvez pela necessidade de justificar Helena, o único exemplo em Homero de referência a um desenho simbólico expresso no labor feminino. Em contrapartida, os elementos referentes à preciosidade do tecido que sai de mãos aristocráticas ou dos materiais usados na sua confecção são uma constante. É discreta, no quadro troiano, a menção do 'tecido enorme, um manto duplo de púrpura' (Il. 3. 125-6), que Helena confeccionava. Mas de regresso à Grécia e à sua casa, anos mais tarde, a Odisseia (4.121-35) repõe na senhora de Esparta o requinte pleno de uma grande dama detentora de todas as suas prerrogativas. Fiar e tecer são, no novo contexto, uma marca de status e uma exibição de elegância. A soberana desfila, vinda da grandeza perfumada dos aposentos e rodeada de servas, com o aparato de uma verdadeira deusa que não despreza aquela que é uma espécie de logótipo da condição feminina, a roca de

\footnotetext{
3 Ainda que G.A. Kennedy (Helen's web unraveled, Arethusa 19.1, 5-14, 1986, p. 6) considere que, em Tróia, Helena está 'como em casa', mais adiante (p. 8) o mesmo autor comenta que a actividade de tecelagem que a heroína executa é um processo de estabelecer 'o lado doméstico da sua personalidade'.

${ }^{4}$ Kennedy, 1986, p. 8, especula sobre os motivos do bordado de Helena: uma representação de Ares? Visível também a própria Helena?

${ }^{5}$ Cf. Kennedy, 1986, passim. Sobre a Helena homérica, vide ainda K.J. Reckford, Helen in the Iliad, GRBS 5.1, 5-20, 1964.
} 
ouro (chryselákatos, 4.122$)^{6}$. Em sua volta, multiplicam-se os elementos de um cenário de luxo, que um serviço bem coordenado vai montando: a cadeira embutida, o tapete de lã macia e o cesto de prata. Por trás deste aparato, o poeta não deixa de salientar o sentido social que lhe subjaz. Helena associa, ao fausto da corte espartana, o exótico de um luxo estranho e importado. Da passagem do casal pelo Egipto, no regresso de Tróia, a soberana trouxe os presentes de hospitalidade devidos à sua condição, de mulher e de rainha: 'uma roca dourada e um cesto provido de rodas, prateado, com os rebordos embutidos com ouro'. A seu lado, como penhor de uma aristocracia que se impõe através de elementos decorativos, o cesto precioso 'vem repleto de fio bem fiado; e sobre ele estava deitada a roca, com lã cor de escura violeta' . Mas se alguns dos objectos que cercam a régia fiadora são 'presentes de Estado', símbolos de uma xenia política, os tecidos por suas mãos confeccionados completam a mesma cadeia social, como presentes de hospitalidade com que a rainha agracia os visitantes no seu palácio. Assim a Telémaco, que o visitara em busca de seu pai, o casal régio cumula de ofertas $(\mathrm{Od}$. 15.104-28); das arcas, Helena retira um tecido luxuoso, 'recamado de bordado, belíssimo, enorme, brilhante como um astro', mas sobretudo confeccionado por suas próprias mãos (15.1078); com a oferta, vai o objectivo, de uma utilidade limitada, ao nível do próprio requinte da prenda; o tecido destina-o Helena à noiva do príncipe de Ítaca, para que o use no dia do casamento. Fausto e generosidade de uma corte elegante, eis o que justifica o célebre episódio.

Por seu lado Ítaca foi sem dúvida a morada da mais famosa tecedeira da antiguidade, Penélope ${ }^{8}$. E, também neste caso, o trabalho feminino é, antes de mais, um instrumento político que uma rainha regente, na ausência do marido, usa com mestria para proteger o trono do assalto ilegítimo dos pretendentes. Assim o reconhece Antínoo, um dos visados (Od. 2.93;105), e a própria Penélope, que o considera um recurso de inspiração divina (19.137). Dolo, a palavra que consagra a estratégia da senhora de Ítaca, é, por isso, também um sinal de inteligência de uma mulher que faz do símbolo da sua frágil condição feminina uma arma de resistência eficaz. No mégaron, Penélope instalou um tear e 'simulou' confeccionar um tecido 'delicado e enorme'. Ao contrário de Helena,

\footnotetext{
${ }^{6}$ Aqui associado a Ártemis, o acto de tecer ou fiar andou sempre, no mito, relacionado com as deusas. Recorde-se o caso paradigmático das Parcas (cf., e.g., Eur. IT 205-7), que fiam o fio da vida.

7 Tradução de F. Lourenço (Homero. Odisseia, Lisboa, Cotovia, 2003).

${ }^{8}$ Sobre as nuances de sentido que o verbo 'tecer' (hyphainein) exprime em Homero, vide C.G. Thomas, 1986, p. 261.
} 
cobriu as suas tarefas de razões de utilidade e de pragmatismo: a preocupação em preservar o fio para que se não desperdice, o objectivo de tecer a mortalha de Laertes, conferindo ao produto do seu trabalho o sentido de um dever doméstico, associa à soberana de Ítaca o traço talvez mais humanizado de uma vulgar dona de casa ${ }^{9}$. E durante quatro anos manteve incólume o trono de Ulisses, no eterno fazer e desfazer da sua teia, que só a denúncia traiçoeira de uma escrava desmontou (2.93-110, 19.137-56, 24.127-46). Apesar deste desfecho, que teria sido infeliz não fosse a chegada salvadora do senhor legítimo do reino, Penélope pode exibir o fruto do seu trabalho que, mesmo se pensado para servir as necessidades da família, nem por isso desmerece do aparato natural do produto de umas mãos de rainha. Perante os pretendentes, Penélope exibe, com orgulho, um tecido acabado, lavado, rival do sol e da lua pelo brilho (24.147-8). Além da teia que a tornou famosa, Penélope partilha com as suas iguais o espectáculo requintado da sua condição: em plena sala de recepções, durante o banquete, reclinada no leito, ela fia (17.96-7); acompanha-a o séquito das servas que, enquanto a imitam na tarefa, partilham da sua intimidade e a distraem (18.313-6), no que é um toque de humanização que Helena não parece praticar. Este mundo feminino, que se concentra em torno da tecelagem como símbolo da sua condição, é por Telémaco oposto ao universo masculino, o da gestão política e das armas. Na hora da matança dos pretendentes, o príncipe sugere à mãe que se refugie no seu círculo de vida, agora que o momento da normalização do poder masculino chegou (21.350-3): 'Regressa aos aposentos e retoma as tuas tarefas, a teia e a roca; ordena às tuas servas que regressem ao trabalho. $\mathrm{O}$ arco é assunto para homens. ${ }^{10}$

A imaginação grega projecta para fora do seu universo práticas semelhantes. Na corte dos Feaces, Arete imita o requinte das suas iguais helénicas; como Penélope, ela fia, em companhia das servas, um fio de púrpura $(6.52-3,305-7)^{11}$, no que é referido como um comportamento de

\footnotetext{
9 À teia de Penélope está também associado um profundo simbolismo sobre o destino da sua vida e da sua casa. Sobre este assunto, vide S. LowEnstam, The shroud of Laertes and Penelope's guile, CJ 95.4, 333-48, 2000, que salienta como o estratagema forjado pela soberana a põe ao nível do herói dos mil artifícios; ao rumo incerto da viagem do herói, que ora o aproxima, ora o afasta da saudosa Ítaca, corresponde esse eterno fazer e desfazer da teia, que é, no gineceu, a prova correspondente da existência da rainha. Vide ainda P. BACRY, Trois fois Pénélope ou le métier poétique, REA 93.1-2, 11-25, 1991; M.H. Rocha Pereira, 'A teia de Penélope', in F. Oliveira (ed.), Penélope e Ulisses, Coimbra, APEC, 2003, p. 11-24.

${ }^{10}$ Esta é uma dicotomia que a comédia virá largamente a explorar. Vide infra.

${ }^{11}$ As próprias fórmulas usadas são denunciadoras da semelhança das tarefas; cf., sobre
} 
rotina. Dos produtos do seu palácio, a rainha tem um controle pessoal e atento; por isso, nas roupas que vestem Ulisses, um estranho ainda no palácio dos Feaces, a soberana reconhece o trabalho das suas próprias mãos e das servas que a acompanham (7.234-5). A opulência está ausente deste cenário, onde o trabalho feminino perdeu em requinte o que ganhou em utilidade. $\mathrm{O}$ afastamento para um universo de fantasia, como as ilhas onde habitam Calipso e Circe, não escapa à uniformidade de um mesmo protocolo. Num cenário que é de vida selvagem, o palácio substituído por uma caverna, a ninfa Calipso tecia, manobrando com agilidade 'a lançadeira dourada' (5.61-2); ao mesmo tempo, liberta da etiqueta palaciana e emoldurada por um quadro bucólico, a ninfa cantava, para entreter a solidão e alegrar o trabalho. Por fim Circe, a feiticeira, imitava-lhe a atitude, também ela cantando enquanto fabricava um tecido lustroso e perfeito, como só mãos de deusa podem produzir (10.221-3; 226-8; 254-5). Ao ouvi-la, à distância, um dos companheiros de Ulisses identifica desde logo a situação, de tal modo a cena é convencional.

Em conclusão, o retrato homérico faz da tecelagem o símbolo por excelência da condição feminina, o único que as damas de corte consideram digno e expressivo de uma etiqueta aristocrática, e da roca o paradigma universal da actividade da mulher.

Ao tomar como seu modelo a tradição épica, a tragédia reproduziu alguns dos seus quadros de referência, sem deixar de imprimir sobre eles certos toques de contemporaneidade. Caso padrão é o de Helena, que Eurípides, inspirado na Odisseia, retrata em Argos, de volta à pátria, no seu Orestes. Depois de ter trazido à cena, perante a infelicidade dos matricidas, a coquette de sempre, Eurípides reproduz a opulência que continua padrão da corte de Menelau. O espectáculo é, neste caso, filtrado pelo testemunho de um servo frígio, uma presença exótica que agora polui a austeridade da velha mansão. É através deste servo que Helena regressa como mulher requintada, que importou, com traços de uma exuberância nova que os contactos fortes com o oriente justificavam na Atenas clássica, modas asiáticas. Enquanto os seus dedos ágeis faziam rodar o fuso, criados frígios abanavam-lhe, junto à cabeça, leques de plumas, transferindo para Argos hábitos da Pérsia. Deste labor, feito de inutilidade e de espectáculo, sai um trabalho faustoso, de linho e púrpura trazidos do oriente, com que Helena pretendia cumprir uma tarefa doméstica: a de tecer, para a irmã falecida, uma oferenda fúnebre (Or. 1426-36). Já não se trata aqui de universalizar uma prática, de que se contamina o desco-

Penélope, 17.96-7, e sobre Arete, 6.53;306. 
nhecido. Eurípides exprime a noção clara do que há de bárbaro no quadro, que, desta vez, invade, por importação, a tradição helénica.

Mas a ideia de que tecer ou fiar são tarefas próprias de uma mulher de ascendente aristocrático continua a vigorar na tragédia como fruto de uma tradição, associada à importância que este trabalho tem ainda na sociedade clássica. Cercada de criadas, Creúsa, princesa de Atenas, dirige-se-lhes como a 'companheiras do tear' (Ion 747-8). Ifigénia, exilada entre os Tauros, que lamenta a perda do seu estatuto de princesa, exprime a sua dor na incapacidade de partilhar as tarefas atribuídas a uma filha de família, na pátria a que pertence (IT 223-8): 'em vez de desenhar, na tela sonora, com a lançadeira, em cores garridas, a imagem de Palas Atena e dos Titãs - ai de mim! -, aqui registro, com sangue, uma desgraça terrível de contar, feita dos gemidos aflitos de gente de fora, que aqui se esgota num vale de lágrimas'. No desenho da teia que recorda, Ifigénia revê um símbolo pátrio e a tranquilidade de uma existência que o padrão de vida grego destinava às mulheres, não como uma penalização, mas como um direito e uma garantia de prestígio social. Perante o público de Eurípides, a filha de Agamémnon trazia à memória, como referência, o peplo da sua deusa padroeira, aquele que, nas Panatenéias, solenemente se ofertava a Atena, saído de mãos de jovens das melhores famílias. Este é uma espécie de símbolo que representa Atenas muito para além das fronteiras da Grécia. Por isso o coro de Troianas, infelizes vencidas de guerra à espera de um destino ainda indeciso, sonha com Atenas, onde possa talvez reencontrar alguma coisa do fausto de Tróia, agora feita em fumo, e do seu estatuto de companheiras de Hécuba (Hec. 466-74): 'Ou, na cidade de Palas, sobre o peplo açafrão da deusa de belo carro, possa eu bordar corcéis atrelados sobre um tecido exótico de tons floridos, ou a raça dos Titãs que o raio luminoso de Zeus adormeceu, num sono derradeiro'. Da privação a que o desfecho da guerra as condenou faz parte a perda da prerrogativa de tecer, que representa, para as Troianas, a ruína do seu enquadramento social (Tr. 199-200). Mas se a guerra se repercute directamente sobre uma população invadida, ela atinge também os que se encontram na retaguarda, num efeito multiplicativo. Antes de mais Ifigénia, como vimos, condenada a um exílio distante, se vira privada, como as mulheres de Tróia, da normalidade da existência; mas Electra, sua irmã, ainda na Grécia sofrera igualmente, graças à ausência do senhor do palácio, um outro afastamento, não tanto marcado pela distância geográfica, como pelo corte com a sua família e condição. Casada com um lavrador, moradora numa triste choupana, Electra mantém, apesar de tudo, o direito de fiar; mas o trabalho que lhe sai das mãos é modesto, como a 
sua nova condição de vida, sem o requinte próprio de uma princesa, mas uma simples tarefa imposta pela necessidade, que a filha de Agamémnon sente como um insulto (El. 307-8).

O carácter pessoal que este tipo de tarefa reveste - que permitiu a Arete reconhecer, como suas, as vestes que o Ulisses náufrago usava, ou a Helena distinguir um hóspede com um presente executado por suas mãos - justifica a utilização dramática frequente do motivo dos tecidos como objecto de reconhecimento. Eurípides, um artista conhecido desta técnica, é disso exemplo. Em três cenas deste modelo, que conservamos da sua produção, Ifigénia, Electra e Creúsa certificam-se de ter encontrado um ente querido pelo testemunho de uma peça de roupa personalizada. Orestes, nas lonjuras da Táuride, descreve a Ifigénia um tecido por ela um dia confeccionado, peça luxuosa que reproduzia um motivo da tradição familiar, o litígio entre Atreu e Tiestes, para além de um vistoso e colorido pôr-do-sol (IT 812-7). Como a aproximação do mesmo Orestes de outra das suas irmãs, Electra, segue o mesmo processo. Em Argos, junto à cabana onde a princesa passou a residir, a roupa que o filho de Agamémnon usava no dia em que uma mão salvadora o arrebatou a uma ameaça de morte, confeccionada pelas mãos da irmã que tem diante, é uma senha de aproximação (El. 538-44; cf. A. Ch. 231-2). Por fim, Creúsa recupera um filho de há tanto perdido, com o recurso a roupas que as suas mãos, desta vez ainda inábeis, de adolescente tinham fabricado; uma Górgona no centro do tecido, franjado de serpentes, não deixa dúvidas, apesar da imperfeição do trabalho que a imaturidade da autora justifica (Ion 1417-25;1489-91).

Mas se a tecelagem é o trabalho por excelência, digno das grandes damas, as restantes tarefas domésticas estão marcadas pelo estigma da humilhação e são próprias de servas. É, no entanto, claro que entre a criadagem feminina existe uma hierarquia, resultante do tempo de serviço ou de uma lealdade comprovada, que faz de algumas das criadas coordenadoras da organização das tarefas, ou lhes permite, em relação aos senhores da casa, uma intimidade privilegiada.

Duas são as designações gerais aplicadas às servas por Homero: amphípoloi, "as que se movem em volta", como as que giram, pela casa, em torno de alguém que as coordena, na realização das várias tarefas (cf., e.g., Il. 3.143, Od. 1.136;335;362, 4.52; 751, 6.52; 84; 217; 239; 246); e, em alternância indistinta com estas, as dmoaí, "cativas de guerra" $(O d .1 .147$, 4.49;296, 5.199, 6.99, 8.433;454, 18.313, 19.25). Só muito pontualmente um epíteto lhes é aplicado (cf. boôpis, "de olhos grandes", Il. 3.144; leukólenoi, "de alvos braços”, Od. 6.239; euplókamoi, "de cabelos encara- 
colados", $O d$. 6.222), que, no entanto, não alude à qualidade do serviço. Todas elas têm na "venerável governanta" (aidoíe tamíe, Od. 1.139, 4.55, $7.175,15.138,17.94 ; 259)$ a coordenadora dos trabalhos, que não deixa de colaborar activamente nas tarefas.

Em qualquer uma das casas régias retratadas por Homero as servas são inúmeras, como múltiplos são também os trabalhos que desempenham. Vemo-las ocupadas em simples gestos de etiqueta, como o de acompanhar as deambulações da senhora pelos vários espaços do palácio, entre os seus aposentos pessoais e a sala de recepções, ou mesmo em qualquer pontual saída ao exterior; em séquito aparatoso, as criadas movem-se com discrição, transportanto os objectos pessoais de uso diário das damas que servem, criando quadros eficientes de um conforto luxuoso. Assim acontece com Helena, em Tróia (Il. 3. 142-5), como também em Esparta (Od. 4.121-35); Penélope, na corte de Ítaca, dispõe de igual aparato (1.332$5 ; 362,4.751,16.413,18.211 ; 302-3 ; 313-4,19.53-5)$. Nessa proximidade com a senhora, partilham com ela, como vimos ${ }^{12}$, a tecelagem, naquela que é, sem dúvida, a tarefa que mais as aproxima, suscitando conversas e confidências. Mas é claro que, além de partilharem desses quadros elegantes, as servas fazem também da produção de tecidos uma tarefa de utilidade, que se encontra, entre os seus ofícios, ao lado de outros considerados mais humildes, como moer o grão; assim na terra dos Feaces, Alcínoo dispõe de meia centena de servas, que se dividem pelas funções de moleiras e tecedeiras (Od. 7.103-6). Das suas mãos saem produtos de aplicação privada e pública, como os tapetes que cobrem os assentos na sala dos conselhos (7. 95-7), merecedores de um reparo elogioso pela qualidade e competência de mulheres, que são verdadeiras artistas do tear (7.109-10).

Marcadamente sociais são todas as outras tarefas servis de manutenção da casa que, numa corte homérica, se repercutem mais sobre as recepções e o exercício de hospitalidade do que sobre o quotidiano privado. De facto, as famílias régias não privilegiam a privacidade. As mansões que habitam, nos espaços comuns como os salões de banquete, ou nos privados, os quartos, são diariamente animadas pela presença constante e numerosa de visitantes e hóspedes, o que coloca exigências pesadas sobre o serviço doméstico. Consideremos, em primeiro lugar, o coração social da casa, a sala de jantar. As tarefas de limpeza e manutenção, antes e depois dos banquetes, não escapam ao registo do poeta. No que funciona como o elenco geral de serviços, Euricleia vigia e organiza o batalhão de servas perante a chegada iminente dos comensais (20.149-54): 'Despachem-se, 
vamos, toca a varrer e a salpicar a casa, forrem os assentos de bons tapetes de púrpura. Passem uma esponja nas mesas, lavem os crateres onde se mistura o vinho e as taças de asa dupla, bem torneadas, enquanto outras vão à fonte buscar água'. Terminada a refeição, segue-se a recolha da loiça (7.232), dos restos de comida e das mesas (19.60-2), ao mesmo tempo que o reforço de lenha no sistema de iluminação e de aquecimento anuncia já a repetição do processo (19.63-4, 22.491-3).

O serviço de mesa, em si mesmo, é de um luxo aparatoso. Uma fórmula, largamente repetida, insiste na preciosidade dos materiais para assinalar o início do banquete, com o acomodar dos hóspedes e o lavar das mãos: 'veio uma serva com um jarro de água, uma peça belíssima, em ouro, de que derramou água numa bacia de prata. Diante deles colocou uma mesa polida'. E logo a governanta se segue com o preâmbulo do jantar, o pão e todo o tipo de iguarias (Od. 1.136-40, 4.52-6, 7.172-6, 15.135-9, 17.91-5). Enquanto a tarefa de trinchar as carnes e o serviço de escanção são funções sobretudo masculinas (Od. 1.141-3, 15.140-1), a atenção permanente de reforço dos alimentos, como o 'empilhar de pão nos cestos ou o dobrar a dose das carnes' mobiliza o pessoal feminino durante toda a refeição $(O d .1 .148,17.259)$. Etiqueta semelhante se pode encontrar fora do mundo aristocrático grego, analogicamente transplantada para o reino da fantasia. Vamos assim encontrar Calipso em pessoa, ao lado das criadas, a servir o seu hóspede, um Ulisses viajante. A própria Ninfa aproxima a mesa e lhe serve as iguarias divinas, ambrosia e néctar, de acordo com a sua qualidade de deusa; a espontaneidade bucólica do lugar justifica a ausência de objectos preciosos, que dão brilho ao serviço no mundo civilizado (5.92-3;196-200). Na ilha de Circe a cena repete-se, desta vez em plenitude, com servas que movimentam em torno do hóspede o brilho precioso das baixelas e a cor atraente dos néctares (10.354-7).

E porque na xenía homérica o aparato do serviço conta, a instalação e acomodação dos hóspedes obedece a um protocolo de elegância equivalente. Oferecer um banho a quem chega de viagem é uma primeira vénia ao relaxamento e ao conforto. Depois de se aquecer ao lume uma panela de água (Od. 8. 433-7, 10.358-60), mãos femininas se encarregam de banhar e massajar o hóspede e de lhe proporcionar roupas lavadas. Este que é um gesto de proximidade com o visitante justifica que, para além de servas anónimas (4.49-50, 8.454-5, 10.361-5), alguma hierarquia seja patente na prestação do serviço. A governanta mantém-se atenta à sua organização e é ela que vem convidar o hóspede quando tudo está a postos (8.44950); ou mesmo, em situações particulares, como foi o caso do encontro de Ulisses com Helena na corte troiana, foi a própria senhora de Esparta 
a prestar esse serviço a um seu compatriota, num ambiente distante (4. 252-3). De regresso ao lar, quando Penélope, ainda na ignorância da sua identidade, ordena às servas, num gesto de rotina, que lavem os pés do recém-chegado (19.317), Ulisses rejeita uma serva jovem, para preferir alguma velha criada, antiga e fiel. Porque a insolência da criadagem mais nova é conhecida e muitas vezes incómoda para os hóspedes (19.370-4), a sua exigência é aceite sem surpresa. Penélope destina-lhe então o serviço de Euricleia, a velha ama $^{13}$ de Ulisses (19.353-8, 386-8, 23.154-5), abrindo, sem o suspeitar, caminho a um novo reconhecimento, que será também mais um passo para a reintegração plena do herói no seu palácio. Assim um simples gesto convencional transforma-se num episódio de grande efeito literário.

Não menos célebre, na saga do herói de Ítaca, é sem dúvida o banho servido a Ulisses na espontaneidade de uma praia, por Nausícaa, a princesa dos Feaces. Longe dos confortos do palácio, a jovem é a primeira a acolher o náufrago e a dispensar-lhe acolhimento; por isso ordena às servas que lhe dêem alguma comida e bebida, e o banhem no rio. À falta do conforto da água quente, escolhe-se um lugar abrigado do vento, onde lhe dispensam roupa e azeite para a massagem (6.209-16; 246). Também aí Ulisses recusa a intervenção das servas e prefere lavar-se sozinho, não por temer-lhes a insolência, mas por um gesto de discrição em quem se encontra, vítima de infortúnio, em terra estranha (6. 218-22).

Confortado com banho e comida, o viajante recebe muitas vezes o benefício de um alojamento confortável. Por ordem da senhora, as criadas preparam os leitos, num quadro onde o requinte vibra nos tons da pintura poética. Uma abundância de mantas e cobertores, de lã ou púrpura, macias, quentes e vistosas, oculta a sobriedade dos leitos (4.296-301, 7.335-9, 19.317-9, 20.138-9). De tochas na mão, as servas conduzem então os senhores ou os hóspedes ao repouso confortável dos leitos (4.300, 19.24-5).

Após a estadia, mais ou menos longa, mas sempre recheada de atenções e solicitude, chega a hora da partida e das últimas diligências, já que, na despedida, são devidos ao hóspede os últimos cuidados. Se Calipso se encarrega pessoalmente de fornecer a Ulisses mantimentos e roupas para a viagem (5. 165-7), à partida do herói da ilha dos Feaces foram as servas que, por ordem de Arete, se encarregaram de os levar até ao navio (13.66-9).

Uma palavra particular é devida a uma personagem destacada entre as servas homéricas, a que a tragédia veio a reservar também um papel

${ }^{13}$ Sobre a figura da ama, cf. infra 
de relevo ${ }^{14}$. Trata-se das amas, mulheres idosas há muito ao serviço dos mesmos senhores, a quem o tempo e a lealdade sempre indesmentida dão prerrogativas especiais no acesso à intimidade da casa e poder na gestão doméstica. Nausícaa beneficia dos cuidados de uma velha mulher de Apire, oferecida a Alcínoo ${ }^{15}$, e que o rei destinara a ser a ama da princesa (7.7-13). Depois de a ter amamentado, a serva tornou-se sua criada particular; é nessa qualidade que a vemos acender-lhe a lareira no quarto e preparar-lhe o jantar. Mas sem dúvida que o paradigma desta personagem em Homero é Euricleia, a ama de Ulisses e, mais tarde, de seu filho Telémaco $(1.435,19.353-5)$. No palácio de Ítaca, ela goza da confiança plena dos senhores, que nela delegam funções de gestão doméstica; sem que ninguém conheça ainda as intenções de Telémaco de partir em busca do pai, é Euricleia quem retira da despensa os mantimentos necessários à expedição (2.348-56;375-80), num gesto de cumplicidade com o príncipe. E, chegada a hora da vingança, também Ulisses lhe pede, de entre as cinquenta servas que ela coordena e que, portanto, conhece como as suas mãos (22.395-6), que identifique as traidoras, para que lhes seja aplicado o merecido castigo (22.417-8;420-5). Este ascendente, que a torna cúmplice na vindicta e no restabelecimento da ordem em Ítaca, faz dela também a mensageira da boa nova junto da criadagem (23.495-6). Mas além deste desempenho, próprio de uma espécie de governanta e procuradora dos senhores junto das servas, Euricleia é o exemplo mais expressivo da afectividade associada ao trabalho. Porque não se trata, da sua parte, de simples eficiência ou de uma lealdade estrita. Homero acentua também o bom conselho (graíes pykimedéos, 1.438) e a afectividade (kédna hiduía, 1.428) com que desempenha pequenos serviços, ou cuidados quase maternos, junto daqueles cuja vida acompanhou desde o início. Vemo-la invadir os aposentos de Telémaco para lhe trazer luz $(1.428 ; 434-5)$, ou para lhe arrumar, com zelo, a roupa que o jovem vai despindo e que, com a negligência própria da idade, lhe vai atirando para as mãos (1.437-42); ou mesmo preparar o leito de um Ulisses, que continua um desconhecido para a esposa dentro da sua própria casa (23.171-2); para ser ainda aquela

${ }^{14}$ Cf., sobre esta personagem e o seu aproveitamento trágico, M.F. SiLVA, 'A Fedra de Eurípides. Ecos de um escândalo’ in Ensaios sobre Eurípides, Lisboa, Cotovia, 2005, p. 167-193; id. Ésquilo, o primeiro dramaturgo europeu, Coimbra, Impr. Univ. Coimbra, 2005, p. 123-5.

${ }^{15}$ A mesma ideia de que as escravas podiam ser oferecidas como presentes de hospitalidade repete-se em 24.278-9, escolhidas pela beleza e dotes de trabalho. Aquiles integra também, como prémio nos jogos que organiza, uma mulher 'hábil em muitas tarefas' (Il. 23.704-5), que avalia em quatro bois. 
que prepara o leito conjugal, como se lhe estivesse reservado intervir, mais uma vez, numa etapa decisiva na vida do grande Ulisses (23.17780;289-92).

Somadas às tarefas internas, que se desenrolam dentro dos palácios, há outras que são, no exterior, a extensão das exigências do quotidiano. Conta-se, entre elas, a lavagem da roupa, responsável por um quadro célebre na saga de Ulisses, a chegada à terra dos Feaces e o encontro com Nausícaa. É curioso observar de que argumentos se serve Atena para levar a princesa até ao rio e proporcionar o encontro. Sob forma de uma repreensão branda, a deusa chama-lhe a atenção para o descuido em que incorre, censurável por se tratar de uma moça casadoira. Apesar do estatuto de princesa, parece natural e até exigível que a filha de Alcínoo se ocupe das roupas da casa. A dimensão social dessa tarefa é também posta em relevo; não só importa que, na festa de casamento que fatalmente se aproxima, toda a família compareça com um aspecto cuidado (6.25-30), como também que se faça a manutenção atenta da roupa dos homens da casa, para que participem nos actos oficiais ou no convívio social arranjados com primor (6.60-5). E esta é, na sua organização, tarefa de Nausícaa e prova da sua arete feminina. Por outro lado, o mesmo zelo que, no interior da casa, evidencia o status de uma família nobre, tem no exterior colectivo uma réplica clara. Porque se trata de uma tarefa vultuosa, dada a dimensão do núcleo familiar, são necessários preparativos diversos: um carro que transporte as roupas e a princesa, enquanto as servas que ajudarão no trabalho seguem ao lado (6.36-40;57-9;68-73;78-84), até aos lavadouros que se situam a boa distância, já fora da cidade. Pelo tempo que o processo exige, é necessário preparar mantimentos, na previsão de um dia completo, em que a princesa e as servas se ocuparão do tratamento da roupa. Com um zelo maternal, Arete em pessoa prepara o farnel (6.76-80) e o óleo para o banho de relaxamento que o rio proporcionará às trabalhadoras. O processo de lavagem resulta num belo quadro poético: nele se destaca a limpidez das águas, frescas e renovadas, e, por isso, capazes de combater a sujidade mais renitente (6.85-7); a diligência das lavadeiras, cada uma empenhando em esfregar a roupa o melhor da sua energia, para depois a estender a secar sob um sol generoso (6.90-5). Cumprida a primeira parte da tarefa, chegou a hora de um lazer merecido: depois de um banho refrescante no rio, fez-se as honras ao farnel. E enquanto o sol seguia o seu trajecto jogou-se a bola, até ao entardecer, quando o dia se pôs e foi possível recolher, já seca, a roupa lavada (6.96-111). Este quadro, de uma naturalidade e beleza poética ímpar, não deixou indiferente Eurípides, senhor de uma sensibilidade pictórica largamente comprovada. 
Na produção que dele conservamos há duas réplicas inspiradas nesta tela, ambas com uma função dramática semelhante: a de pôr em contraste a frescura e a vitalidade de um grupo de servas, que se ocupam na lavagem da roupa, com a dor mortal das suas senhoras. Assim em Trezeno (Hipp. 121-40), servas diligentes de Fedra, numa corrente de água viva, mergulhavam o purpúreo das roupas, para depois as exporem, sobre os rochedos, ao calor do sol; ao mesmo tempo que, na penumbra do palácio, à sombra de um véu que lhe oculta o rosto, Fedra sofre de um mal desconhecido, mas profundo. Helena, exilada no Egipto, vive uma experiência semelhante (Hel. 179-90); enquanto as servas, 'junto às águas de um azul profundo, estendiam sobre a erva frisada os tecidos de púrpura, sob os raios dourados do sol', a rainha de Esparta soltava um grito sofrido, expressão de uma dor extrema e íntima. À frescura dos traços homéricos, Eurípides acrescenta a policromia contrastante da paisagem e das roupas, num aparato poético; mas sobretudo cria, ao lado de uma tela de vida, um cenário recolhido de inactividade e penumbra, onde se esconde uma mulher infeliz; ou seja, retira do quadro da Odisseia a juventude vibrante de Nausícaa, participante activa nas tarefas, e substitui-a por uma soberana mais madura, que experimentou as penas de um casamento em crise, mergulhada, na sombra e na distância, em tremenda solidão e sofrimento.

Uma moldura mais rústica assinala, em Homero, a existência de um outro mundo, para além daquele que as paredes dos palácios delimitam. No escudo de Aquiles, Hefesto retratou o trabalho das vindimas, em que rapazes e raparigas participam na recolha dos frutos e no transporte dos cestos (Il. 18. 566-568). Mas o palácio de Ulisses possui também doze moleiras, encarregadas da tarefa penosa de moer o grão (20. 105-8). O cansaço que se segue ao labor ou a fraqueza que se apodera das menos resistentes (20.109-10;118-9) marca bem o esforço envolvido neste outro trabalho, mais penoso do que o de interior. Mais resguardadas, às criadas de sala sobra ainda frescura e folgança para viver, com os pretendentes, condenáveis aventuras românticas. Há também, à distância dos palácios, as habitações modestas onde residem as famílias humildes. Foi aí que se refugiou o velho Laertes, depois que a sua corte, abandonada pelo legítimo senhor, se afundou na ruína. Velho e desprotegido, o soberano de outrora tinha consigo uma única serva, uma mulher siciliana, que lhe prestava, na modéstia de uma casa rústica, cuidados elementares (24.2112;365-7;388-90).

Em plena época clássica, a tragédia conservou, em diferido, uma imagem desta tradição aristocrática, que, no entanto, submeteu a conceitos de vida seus contemporâneos: aqueles que se instalaram num regime 
de vida democrático, numa cidade mergulhada na crise que uma guerra prolongada produziu. No teatro de Eurípides, este processo, que apeou dos seus pergaminhos as antigas heroínas, está envolvido com a ideia de escravatura que a guerra desencadeia. Simbolicamente despojadas do seu tradicional ascendente, rainhas e princesas viram-se reduzidas à condição de servas e obrigadas às tarefas correspondentes. Mais do que obedecer a uma inevitável hierarquia, o trabalho passou a traduzir necessidade e humilhação; tarefas que, na épica, separavam classes passaram, agora, tragicamente a uni-las. Hécuba, Andrómaca e Políxena são exemplo dessa escravidão insultuosa que as espera na terra do conquistador. Dando voz ao sofrimento geral, Hécuba lamenta-se (Tr. 190-6): 'Ai de mim! Onde, em que terra, nesta idade, serei escrava? (...) Ficar de guarda à porta ou cuidar de crianças há-de ser tarefa daquela a quem Tróia prestava homenagens de rainha'16 (cf. Tr. 491-3). A estes, outros trabalhos 'igualmente intoleráveis' se juntam: fabricar o pão, varrer, ir buscar água à fonte, tecer (Andr. 166-717, Hec. 362-4, Tr. 205-6;494). Escapar a tal humilhação leva Políxena a preferir, voluntariamente, a morte. Deste contexto poético, Eurípides, em consonância, retirou, de um modo geral, o ornamento pictórico, deixando mais visível o lado simplesmente utilitário e vulgar, que ofende o sentimento de status daquelas que lhe estão sujeitas.

Por aproximação com as cativas de guerra, tanto mais expressiva se torna a situação, que Eurípides criou, de Electra, a princesa de Micenas, exilada e escravizada na sua própria terra, por vontade da mãe. Para maior ironia, Electra não é concubina de um senhor poderoso, mas legítima esposa de um lavrador. A humildade dos trabalhos que executa, na nova casa a que passou a pertencer, não é o castigo de um vencedor sobre um vencido, mas a simples normalidade de um quotidiano onde as princesas perderam o seu lugar. Da controvérsia que, no mundo real, terá acompanhado a progressiva revolução social, dá conta a fúria de Electra, que a empurra para a vingança extrema do matricídio. Da sua nova condição, ligada a uma casa humilde em ambiente rústico, Electra faz questão de dar espectáculo, para que brade aos céus a humilhação que a vitima (El. 120-1). Exposta fora de casa, à vista de todos, ei-la, noite ainda, a caminho da fonte, de cântaro à cabeça, mal vestida, com as roupas por suas mãos tecidas ( $E l$. 54-9;307-9); que o efeito que pretende é conseguido prova-o a reacção de Orestes que, ao avistar à distância aquela mulher desconhecida, a toma,

${ }^{16}$ O serviço de porteira é também desempenhado por uma velha no palácio do faraó, em Eur. Hel. 437 sqq.

${ }^{17}$ Cf. Il. 6. 456. 
pela aparência, por uma escrava $(E l \text {. 107-9 })^{18}$. Mas se Orestes reconhece, na figura que observa, tons de plebeia, orientado pela convenção que vigora em sua volta, a própria Electra, de acordo com os mesmos pressupostos, é capaz de criar, em imaginação, a pose de grande dama que Clitemnestra mantém no seu palácio, num aparato inactivo de antigamente (El. 314-8): 'a minha mãe, essa, entre despojos da Frígia, vive sentada num trono. Nos degraus, cativas da Ásia trazidas pelo meu pai, como outrora em Tróia, usam vestidos presos com fivelas de ouro'. Ao lado da raiva por uma mãe que a coloca abaixo das cativas que a servem - a corte de Micenas é ainda um reduto de ascendente aristocrático, na ignorância de um mundo novo que a olha com ressentimento e se apressa a derrubá-la -, Electra nutre um outro sentimento, este de inspiração democrática; o de solidariedade para com um marido humilde, mas dedicado, que trabalha para sustentar a família (El. 71-1). O seu lar é afinal o retrato da casa padrão de uma classe popular, aquele em que o marido trabalha fora, a tratar do gado e dos campos, enquanto a mulher se ocupa da lida da casa e de garantir algum conforto ao homem que regressa, cansado, ao fim do dia. De recursos modestos, este padrão de vida exige esforço e autonomia: o da mulher, que assegura as roupas necessárias, sem luxos nem aparatos, e que faz o milagre de improvisar, de uma despensa pobre, a refeição quotidiana (El. 421-5 $)^{19}$. O desajuste entre a condição aristocrática, mesmo se decadente, neste outro universo de realismo é flagrante.

Por isso Electra será talvez, na cena trágica, a figura de mulher que mais se aproxima da realidade da Atenas clássica, de que coube à comédia traçar o retrato mais fiel. É urbano o quadro desenhado pela comédia, saído do quotidiano de uma cidade em guerra, onde a crise instalada sobre as famílias está bem visível. O tear continua a ser, na Atenas do séc. V como no mundo épico, o logótipo feminino. Também Eurípides, em Bacantes, o deixou claro, ao opô-lo, em antinomia, aos tamboretes que animam o culto dionisíaco. Aderir ao culto do deus significou para as mulheres 'deixar tecidos e teares', ou seja a casa e a rotina que o nomos lhe impunha, por uma nova ordem, estranha e inaceitável na sociedade grega ( $B a .116-9)$. Como garante dessa ancestral normalidade, Penteu ameaça fazer frente a um invasor desconhecido e reinstalar a ordem, quando proclama ( $B a$.

\footnotetext{
${ }^{18}$ Sobre a escassez de escravos na época clássica, certamente reservados para tarefas domésticas, cf. M. Balme, Attitudes to work and leisure in Ancient Greece, G\&R 31.2, 140-52, 1984, p. 145.

${ }_{19}$ Praxágora reconhece à mulher este mesmo predicado, de improvisar, com recursos modestos, a refeição da família (Ar. Ec. 234-5).
} 
513-4): 'vou arrancar-lhes das mãos ruidosas esse tamborete de couro sonoro e ocupá-las no tear, como servas sob minha autoridade'. Mas é a comédia o cenário que melhor reproduz a rotina da mulher clássica e o quadro de trabalho de que está incumbida ${ }^{20}$. O testemunho cómico é consensual com todos os outros testemunhos, quando adopta a tecelagem como uma insígnia feminina. Uma dona de casa prendada e activa, que se impõe por essas qualidades à consideração do marido, é a que sabe fiar (Ar. Nu. 53-5). E não o faz por mera exibição de elegãncia ou de requinte; fá-lo para satisfazer as necessidades da família (Ar. Ec. 88-93), vestindo os filhos ou vendendo no mercado o produto do seu trabalho (Ar. Ra. 1346-50). No difícil jogo da harmonia conjugal, a tecelagem é usada como uma estratégia sentimental ou de sedução. As companheiras que, com Lisístrata, se barricaram na Acrópole em greve ao sexo, usam a lã e o linho, em casa ao abandono e a precisar de cuidados urgentes, como um pretexto para furar a reclusão e promover um encontro com os maridos (Ar. Lys. 729-41); retomam, com esses argumentos, o dolo usado por Penélope, para adiar as pretensões dos candidatos à sua mão. Mas é também no crochet 'arrastado pelas patas das galinhas' que Cinésias se inspira, para demover Mírrina a abandonar a greve e a voltar para casa, certo de que a sensibilidade bem feminina da mulher não resistirá a este símbolo da degradação familiar (Lys. 896-7).

À tecelagem, outrora uma tarefa elegante, hoje resposta a necessidades concretas, a mulher clássica junta todas as outras actividades domésticas, dantes atribuídas à criadagem (Lys. 17-19): 'é uma que se ocupa do marido, outra de acordar um criado, outra de deitar o filho, de lhe dar banho ou de lhe fazer a papa'. Na cozinha (Lys. 601), na lida da casa (Lys. 894-5, Ar. Th. 401-3), no cuidado dos filhos (Lys. 880-2;956), a mulher de classe média tem uma intervenção directa. A sua ausência, ou a greve que a utopia lhe permite fazer, lançam no caos a vida doméstica e deixam em desespero a incompetência dos maridos. É por suas mãos que está assegurada uma rotina, constante e necessária (Ec. 215-23b): 'mergulham as lãs em água quente, à moda antiga (...). Fazem os grelhados sentadas, como dantes; trazem fardos à cabeça, como dantes; cozem o pão, como dantes'. Sem a interposição de governantas, são também elas que, a par da execução prática da lida doméstica, chamaram a si a administração e a autoridade sobre a despensa (Th. 418-23) e a organização da casa (Ec. 211-

${ }^{20}$ Ver também V.I. ANASTASIADIs, Idealized scholê and disdain for work: aspects of philosophy and politics in ancient democracy, CQ 54. 1, 58-79, 2004, e R. BROck, The labour of women in Classical Athens, CQ 44. 2, 333-46, 1994. 
2). Até as tarefas, outrora reservadas a escravas, que exigem a exposição fora de casa, começam a competir também às mulheres de família. É o caso das companheiras de Lisístrata que, enquanto os maridos lutam nos campos de batalha, se disputam também elas com as criadas na fonte, por um cântaro de água, no terreno que passou a ser, no feminino, o campo da luta diária pela vida (Lys. 328-34).

Mas a crise exigiu mais ainda da sociedade democrática. As mulheres de menor poder económico passam a exercer activamente uma profissão fora da estrita lida da casa. O mercado anima-se com a presença de vendedeiras de produtos variados, conhecidas pela energia e por uma agressividade temível, a que sem dúvida as exigências do quotidiano as obrigaram. Hortaliceiras, padeiras, floristas (Lys. 456-8, 562, 564; Th. 387, 446-8, 455-6, Ar. Ra. 840), taberneiras ou estalajadeiras (Lys. 458, Th. 347, $R a$. 549-78), as mulheres vão penetrando, pela necessidade, no mundo dos negócios e do exterior, tradicionalmente masculino. A viuvez ou a simples ausência dos maridos no campo de batalha a isso as obriga.

Em consequência de um novo modelo social, para mais afectado pela tremenda crise que um conflito longo produzia, a mulher, mais isolada e por isso também mais interveniente, ganha uma visibilidade e uma importância social que a comédia traduz em utopia ${ }^{21}$. Longe vai o tempo do ascendente que rodeava as damas de corte, refugiadas na elegância dos salões, senhoras das casas é certo, mas confinadas a um mundo bem delimitado e distinto do dos heróis, seus companheiros ${ }^{22}$. Com a democracia, as paredes das casas ameaçam ruir e os primeiros sinais de uma aproximação com o universo masculino surgem na imaginação. À pergunta: se faliu a organização social conduzida pelo talento masculino, porque não ensaiar a sua substituição pela mulher, a comédia, como registo da nova ordem dos tempos, responde em vários tons. Se as provas dadas pelas mulheres na lida doméstica produziram sempre tão bons resultados, salvaguardando até ao limite a sobrevivência das famílias, porque não confiar-lhes a gestão da cidade? Seria, afinal, um milagre ao alcance da mão, o de estender à casa comum - uma Atenas em crise - os dotes comprovados das mães de família; cozinhar e tecer, com regra, sentido de poupança e eficiência, eis o que pode ainda salvar uma sociedade mergulhada na pobreza (Ec. 599-600, 653-4, 714-6, 845).

${ }^{21}$ Esta é uma novidade desconhecida da mulher épica que, para além da intervenção no oîkos, não tinha qualquer papel no mundo exterior. Cf. C.G. Tномаs, 1986, passim. ${ }_{22}$ A despedida de Heitor e Andrómaca (Il. 490-2) contém já, clara, esta discrepância, a que separa a mulher gestora da sua casa e activa no tear, do herói, senhor da guerra. 
Porque afinal - símbolo supremo - a política não passa de um novelo (Lys. 567-88), que é preciso dobar com competência, tarefa em que as mulheres, desde que o mundo é mundo, se mostraram verdadeiras fadas.

TitLe. Women's labour in Ancient Greece: legend and reality

ABSTRACT. This article evaluates diacronically the work of women in ancient Greece and its evolution from the archaic till the classic times, using epics and theatre as main testimonies. Social organisation, more aristocratic or more democratic, or other essential civic elements as war, populational instability, economic conditions are taken into account.

KEYwORDS. Homeric poems; theatre; tragedy; comedy; domestic or civic work; leasure. 